\title{
The Influence of Changes in Taiwan's Legislative Electoral System on the Democratic Progressive Party (2008-2012)
}

\author{
Kuo-wen Kuo ${ }^{1}$ \& Hsiang-yi Yeh $^{1}$ \\ ${ }^{1} \mathrm{Ph} . \mathrm{D}$. Candidate, Graduate Institute of Political Economy, National Cheng Kung University \\ Correspondence: Kuo-wen Kuo, Ph.D. Candidate, Graduate Institute of Political Economy, National Cheng Kung \\ University
}

Received: April 23, 2015

Accepted: April 30, 2015

Available online: April 29, 2015

doi:10.11114/ijsss.v3i3.802

URL: http://dx.doi.org/10.11114/ijsss.v3i3.802

\begin{abstract}
Elections to the Legislative Yuan in Taiwan are crucial to the exercise of national legislative power, and an important mechanism for popular participation in decision making through representative politics. This study looks at the historical consequences of the political demands for a "single member, dual ballot" electoral system and "halving of legislative seats" during Taiwan's democratization process, and the resultant path dependence for Taiwan's legislative elections, from which the mixed-member system with two ballots in single member constituencies emerged as the direction for constitutional reform. This constitutional amendment project driven by cooperation between the two major parties in Taiwan ultimately produced a disproportional outcome, under which the Kuomintang (KMT) as the largest party has enjoyed a dominant position due to over-representation, while the number of seats won by other parties was reduced. This may not have been the result originally anticipated by the Democratic Progressive Party (DPP). However, changes in the electoral system occur in the context of path dependent dilemmas. Only a new wave of constitutional revisions can correct the large difference between legislative representation and the structure of the electorate, and bring the system closer to the basic principles of representative politics under democracy.
\end{abstract}

Keywords: electoral reform, single-member dual-ballot, party preference, path dependence

\section{Introduction}

On January 12, 2008, the results of the Seventh Legislative Elections in Taiwan were announced, causing significant interest and surprise. The interest was due to the importance of the legislative elections and their influence on the upcoming presidential election. The surprise was that in the first election after the electoral reform, there was such a great disparity in the number of seats won by the ruling and opposition parties. Even in 2012, the second election after the reform, there was still a large gap between the two parties in how vote share translated into seats, despite the reduction in negative political factors affecting the DPP's performance.

Taiwan used a single non-transferable vote (SNTV) system for a total of seventy years, beginning in 1935 under Japanese colonial rule, and ending with the Sixth Legislative Elections in 2005. However, the negative effects of SNTV impacted both campaign strategies and the performance of legislators ( Wang,2008:33).For these reasons, when demands for reform of the legislature emerged in the mid-1990s, changing the electoral system to a single-member dual-ballot system was a key objective. However, following the first transition of power, the ruling party became a minority in the legislature. Against the backdrop of the conflict between the executive and legislative branches, demands emerged for a further reform to the legislature - a halving of the legislative seats. Finally, following the 2004 presidential election and prior to the Sixth Legislative Election, constitutional changes to the legislature were passed, ${ }^{1}$ including the introduction of a "single-member dual-ballot mixed member majoritarian system." The effect of the new electoral system was a dramatic reduction of the opportunities for candidates from small parties and independents to get elected. As a result, Taiwan began to shift towards the two-party system predicted by Duverger's Law ${ }^{2}$, or even toward a one-party dominant system.

\footnotetext{
${ }^{1}$ Please refer to Additional Article 4 of the Constitution and the relevant provisions Article 67 in the Civil Servants Election and Recall Act.

2 Duverger,Maurice,1986, “Duverger's Law: Forty Years Later”, in Bernard Grofman, and Arend Lijphart, eds., Electoral Law and Their Political Consequences, New York: Agathon Press, pp69-84.
} 
This study is not focused on the party system produced by the new electoral system, but is instead concerned with how institutional preferences shaped decision making, using the example of the Democratic Progressive Party (DPP). We also explore the gap between the DPP's expectations and the eventual outcome of the electoral reform, which produced a system that was clearly advantageous to the Kuomintang (KMT). The new system has created significant disproportionality, meaning an over-representation of the KMT in terms of seat share. The mixed member majoritarian system (MMM, otherwise known as the parallel single- member dual-ballot system) allocates a fixed number of seats according to each party's share of the vote in a separate party ballot that is not linked to the number of seats won in the constituency ballot. However, in the mixed-member proportional system (MMP, otherwise known as the top-up system or compensatory system), the total share of seats obtained by each party is determined by its share of the vote. The constituency seats won by each party are first deducted, before awarding top-up seats proportional to each party's vote share. Aside from the differences in proportionality, following Duverger's Law, an electoral system based on single member constituencies is more likely to produce a two-party system, while a proportional system is more likely to produce a multiparty system. Comparing Duverger's views on the electoral system and party system, single member plurality systems will mechanically produce under-representation of smaller parties, meaning that the proportion of seats won by smaller parties is lower than their share of the vote. In addition, from a psychological perspective, voters will make rational calculations when faced with a particular election environment. Since voters do not want to waste their vote, they may choose to vote for their second preferred candidate. In particular, under single member plurality voting, voters feel that candidates from small parties have a low chance of getting elected, meaning a vote for a candidate for a smaller party is likely to produce a wasted vote. They will therefore switch their vote to another party which they did not originally support, but are also not adverse to, in order to prevent a party that they do not like getting elected. "Parallel voting" in the MMM system is also majoritarian. In particular, when the proportion of members elected through majority voting is high, the disproportionality produced by the mechanical factor will create more significant over-representation.

Other factors producing over-representation include the drawing of constituency boundaries and the method for electing constituency seats. The 2004 constitutional amendment passed by the Legislative Yuan included the single-member dual-ballot system, the halving of the seats in the Legislative Yuan, abolishing the National Assembly and incorporating referenda into the constitution. Aside from the overrepresentation caused by the disproportionality of the MMM system, according to Article 4 of the revisions to the Constitution and Article 67 of the Civil Servants Election and Recall Act, the allocation of single member constituencies is based on counties and cities as constituency boundaries. This rule failed to take into account the democratic principle of "votes of equal weight," and resulted in the malapportionment of constituencies. In addition, aside from the unfair drawing of constituency boundaries, the movement of people produced another form of over-representation(Rein,T \& Matthew,S.,1989). The redrawing of electoral boundaries was inevitable given the changes in the electoral system. However, the distribution and creation of seats was also influenced by the halving of number of seats, creating a "double disproportionality" in the constitutional reform. Therefore, the disproportionality in the new electoral system came from both the introduction of the single-member dual-ballot MMM system and the halving of the seats in the Legislative Yuan.

From the above comparison of vote share and seats won, MMP systems have greater proportionality. In contrast, MMM systems are mixed member systems with lower proportionality and greater emphasis on the single member constituencies, making the over-representation caused by disproportionality more apparent, clearly benefitting large parties, and producing a trend towards a "dominant large party." From the perspective of institutional development, the continued use of this new system will produce a stronger possibility of the emergence of a dominant one-party party system. In addition, since the disproportionality caused by the halving of the seats in the Legislative Yuan produced another form of overrepresentation, a new "double disproportionality" emerged. This "double disproportionality" reduced the available space for small parties, producing a two-party system, or even a one-party dominant party system.

This study looks at the historical conditions created by the political demands for a single member, dual ballot electoral system and halving of legislative seats, using path-dependence to explore how the process of legislative reform locked in institutional choices. The path of institutional change is normally subject to existing historical conditions. Although historical institutionalism accepts that history is created by contingent historical events, existing historical conditions create certain constraints on future development. Historical institutionalism refers to these constraints as historical legacies, exploring how path dependence created by historical conditions locks in the process of institutional change.

\section{Looking at Electoral Reform from the Perspective of Path Dependence}

Due to space limitations, this study does not discuss the new electoral system in detail. Instead, we begin from the perspective of historical institutionalism and path dependence theory to explain the process of electoral reform. Ellen Immergut's historical institutionalism can be divided into three main parts. First, historical institutionalism believes that humans are characterized by alternative rationality, and understands human behavior by placing it in an historical 
context. Historical institutionalism believes that there is a causality behind historical events. Therefore, historical institutionalism emphasizes historical context when examining the causality of different events. In addition, scholars in this tradition also emphasize contingency when explaining the emergence and development of historical events. Therefore, history cannot be explained using a single logic. This approach enables researchers to trace previous events to identify future policy solutions (Immergut ,E. 1998, 5-34). In addition, from Peter Hall and Rosemary Taylor's definition of historical institutionalism, we can identify several related points: a tendency to use broader vocabulary to conceptualize the relationship between institutions and the behavior of actors; emphasis on asymmetrical power relations in the development and operation of institutions; a tendency to emphasize path dependence and the unintended consequences of institutional development; special focus on the integrated analysis of institutions and the possible influence of other factors such as the perspectives of actors on political outcomes (Hall,P.\&Rosemary,T.,1996:938). Based on the perspectives of these scholars and other important researchers in historical institutionalism, the main arguments of historical institutionalism can be summarized as follows: a belief that history may be produced by contingent factors, but that the appearance of historical contingency and critical junctures produces causality, influencing behaviors, relationships, and policy outcomes with in a specific time and space, as well as the subsequent path of institutional development.

With regard to the influence of historical contingencies on the direction of historical development, historical institutionalism frequently uses the perspective of path dependence to explain historical development. According to the economists W. Brian Arthur and Douglas North who developed the concept, path dependence means that in the process of institutional change, positive feedback and self-reinforcement occurs, meaning that when institutional change takes a certain path, it becomes difficult to change direction. In other words, historical development is "locked in" to a certain path. Path dependence mechanisms can even mean that institutions become locked into an inefficient state. Once institutions are locked in, it becomes very difficult for them to change. Often change is only possible through the intervention of external forces or exogenous variables. There are two main models of institutional change. The first is bottom-up induced institutional change, meaning changes or proposals regarding existing institutional arrangements, or the creation of new institutional arrangements. The second is top-down imposed institutional change, meaning that the government uses executive orders or legal means to promote institutional change. In the real world, the process of institutional change is always a combination of induced institutional change and imposed institutional change(Wang,1997:80-95).

Following the above outline of the main features of historical institutionalism and path dependence, this study looks at the important institutional features affecting political development. Aside from "cost-benefit" calculation as a motivation driving institutional change, the occurrence of historical contingencies drives institutionalization in a certain direction, producing a self-reinforcing effect, while also interacting with other political and institutional mechanisms. As a result, historical development may become locked into its original path, ultimately producing a restraining effect on political interaction and political processes. In this study, we base our analysis on "contextualizing institutions," examining the social and environmental context behind political decisions that occur in specific decision making situations(Lin,2000).

\section{The Processes behind the Emergence of the New Electoral System}

The political demands for a single-member dual-ballot system and halving of the seats in the Legislative Yuan emerged at different times and in different contexts. Eventually, constitutional changes reforming the legislature were passed following the 2004 presidential election and before the Sixth Legislative Election. ${ }^{3}$ In the following year, the proposals received majority support in an ad hoc National Assembly, formally ratifying the constitutional amendments. The political demands of the two major parties during this process are described below.

\section{(1) Promotion of the Single-Member Dual-Ballot System and Emergence of Consensus on the MMM System}

Single-member dual-ballot system include the German MMP system and the Japanese MMM system. However, from the mid-1990s onwards, there was no clear distinction between the two in the calls for the replacement of the SNTV system with a single-member dual-ballot system. In 1995, premier Lien Chan publically called for a "single-member dual-ballot" system as the direction of future reform to the electoral system. The next day, President Lee Teng-hui echoed Lien's call, arguing that a single-member dual-ballot system would help candidates who focused on servicing the grassroots. ${ }^{4}$ In October 1996, the Japanese House of Representatives used a single-member dual-ballot MMM system for the first time. In December of the same year, the ruling and opposition parties convened a National Development Conference and reached agreement that "elections for national legislatures use a mixed dual ballot system

\footnotetext{
${ }^{3}$ Please refer to Additional Article 4 of the Constitution and the relevant provisions Article 67 in the Civil Servants Election and Recall Act.

${ }^{4}$ See Central Daily News. December 7, 1995, 4th edition (in Chinese).
} 
consisting of single member constituencies and proportional representation, and to establish a cross-party working group for deliberations." In the same National Development Conference, party members including Huang Teh-fu publically announced the KMT's core positions on electoral reform, including the proportional representation element accounting for $20 \%$ of the total seats, and a MMM system where the calculation of proportional representation seats was not linked to the distribution of constituency seats. ${ }^{5}$ However, in the fourth round of constitutional revisions in July 1997, due to a lack of consensus between the KMT, DPP, and New Party on whether to adopt the German MMP system or the Japanese MMM system, these reforms were not included in the round of constitutional revisions(Wang,2008:107). However, prior to the fifth round of constitutional reform in 1999, the Central Election Commission (CEC) released a report assessing single-member dual-ballot systems. In the report, the CEC noted that it German model would be more difficult to apply in Taiwan, and that it preferred the Japanese model. ${ }^{6}$ During the campaign for the 2000 presidential election, the three main candidates Chen Shui-bian, James Soong, and Lien Chan all included the single-member dual-ballot system in their campaign promises. The following year, Lien publically stated that in order to ensure political stability and prevent excessive vote splitting, the Japanese MMM system should be adopted. Furthermore, the proportion of constituency legislators should not be too low(Lien,2001:96). These statements reiterated the KMT's basic demands for the electoral reform.

After the ruling and opposition parties agreed to move toward a single-member dual-ballot system at the National Development Conference, controversy emerged over the format of the new election system. For instance, as described above, differences emerged between the ruling parties on the electoral system in the 1997 Constitutional Reform Meeting. In the KMT proposal, the number of legislators would be set at 200, with a single-member dual-ballot MMM system. Three-quarters of the legislators would be elected in the single member constituencies, while the remaining one-quarter would be elected by proportional representation. Internal party discussion papers declared that the "German system benefits small parties and should not be considered; the Japanese system benefits large parties, and should be adopted in the constitutional amendment." ${ }^{\text {"7 }}$ In contrast to the KMT's proposed constitutional amendments, the DPP and New Party advocated the German MMP system, while scholars sympathetic to the DPP were vocal in their calls to adopt the German system, since the Japanese MMM system would result in the perpetual rule of the Kuomintang. ${ }^{8}$

Following the first transition of power, the People First Party (PFP) and Taiwan Solidarity Union (TSU) were established, and Taiwan appeared to be moving toward a multiparty system. Following the 2001 legislative elections, the political map in the legislature was transformed, with the DPP becoming the largest party in the legislature, and the KMT relegated to second place as its votes were siphoned off by the PFP. In the following year, the presidential office convened a Government Reform Commission. Four working group meetings examining legislative reform discussed draft proposals produced by scholars and determined the content of reform proposals. In the fifth commission meeting in May of 2002, it was determined that the electoral reform should adopt single-member dual-ballot MMM system. ${ }^{9}$ Shortly thereafter, the DPP Central Standing Committee announced its support for the government proposal. In May of the same year, the standing committee passed the DPP version of the constitutional revisions to the legislature. This blueprint reduced the number of seats to 150 and officially confirmed the DPP's support for the MMM system. ${ }^{10}$

In discussions between the opposition and ruling parties during the second half of the 1990s on constitutional reform proposals, there was no consensus between the ruling party and opposition of whether to adopt the MMM or MMP system. Following the first transition of power and the Fifth Legislative Election, with the increasing fragmentation of the party system and the transformation of the political situation, a consensus on the electoral system began to emerge between the major parties. Subsequently, the seventh round of constitutional revisions were completed following the

\footnotetext{
5 See China Times, December 25, 1996, 2nd edition (in Chinese).

6 See Taiwan Daily. January 6, 1999, 4th edition (in Chinese).

7 See China Times, June 6, 1997, 2nd edition (in Chinese).

${ }^{8}$ For the position of the DPP and its officials, as well as Pan-Green scholars, see China Times, March 25, 1997, $3^{\text {rd }}$ edition (in Chinese); Commons Daily. March 15, 1997. $12^{\text {th }}$ edition (in Chinese); Taiwan Daily. May 24, 1997, $7^{\text {th }}$ edition (in Chinese).

9 The fifth committee meeting produced the following principles for legislative reform:

1. Adoption of a single-member dual-ballot system for legislative elections. In simple terms, this meant that the entire country should be divided into the same number of electoral districts as district members, with each district electing one member. Each elector would cast two ballots, one for the district member, and one for a political party.

2. District members should account for $60 \%$ of the seats, while at-large members should account for $40 \%$ of the seats. Political parties nominate a closed list of candidates, and seats are allocated based on each party's vote share, with candidates elected in the order in which they appear on the party list. Any party that achieves at least $5 \%$ of the national vote is eligible for at-large seats. see: http://www.president.gov.tw/2_special/innovation/t6.html, accessed on December 13, 2008 (in Chinese).

10 See Liberty Times. May 29, 2002 (in Chinese).
} 
200 presidential election.

\section{(2) The Halving of the Seats in the Legislative Yuan and the Passage of the Constitutional Amendments}

Following the first transition of power, the government now had a minority of seats in the legislature. Due to the divided government and constant conflict between the executive and legislature, the public had an increasingly negative view of the legislature. Although the DPP significantly increased its seats share in the Fifth Legislative Election, becoming the largest single party, the government continued to be divided.

However, as the demands for halving of the seats in the Legislative Yuan and a single-member dual-ballot system were very different in nature, they had different potential impacts. Despite this, they were both labelled as progressive demands for "legislative reform." At the same time, the halving of the seats in the Legislative Yuan enjoyed high public support, meaning that it became the main driving force for the seventh round of constitutional revisions.

The idea of halving the seats in the Legislative Yuan was first proposed by DPP legislators including Chang Hsueh-shun and Wang Sing-nan. On November 24, 2000, the published advertisements in major media outlets on "downsizing the legislature" in order to gain support, and organized a large scale demonstration on December 25 of the same year, promoting the policy under the name "Action Alliance to Halve the Legislature"(Lin,2002:414). The demands of the Alliance can be summarized as follows: (1) Halving the number of legislators, and increasing the "representativeness" of legislators; (2) "Reducing quantity to control quality," enhancing the political capabilities of legislators; (3) Other additional benefits such as making savings in government expenditure and making vote buying more difficult (Wu \& Chuang,2000). However, $\mathrm{Wu}$ and Chuang's advocacy of "reducing quantity to control quality" was challenged internally by the DPP's Policy Research and Coordinating Committee, who argued that the interaction between the number of seats and functioning of parliament in Western democracies demonstrates that the number of legislators is not the central issue. Reducing the number of seats in the legislature was a part of the legislative reform, but it was also only a stopgap measure. A resolution to the malfunctioning of the legislature had to start from the most fundamental problem - reform of the electoral system(Chiang,2001).

The demand to halve the seats in the Legislative Yuan obtained a considerable degree of public support, while also receiving the backing of the Mainstream Alliance faction within the DPP. Subsequently, the DPP Central Standing Committee reached a consensus on the policy of halving of the seats in the Legislative Yuan, which the party's legislative caucus was instructed to push forward. ${ }^{11}$ In addition, in the first session of the fifth term of the Legislative Yuan, TSU legislators began collecting signatures for a constitutional amendment to halve the number of legislators. At the end of February, more than $25 \%$ of legislators had signed the proposal, meeting threshold for putting forward a constitutional amendment. In August the same year, the TSU incorporated the demand for the halving of the seats in the Legislative Yuan into its "Twelve Item Policy Statement," making it into a major policy direction for the TSU and an important part of the party's appeal to voters.

At the same time, the DPP was also actively pursuing legislative reform. In a speech to the DPP's national convention in October 2001, president Chen Shui-bian linked the policies of the single-member dual-ballot system and halving of the seats in the Legislative Yuan for the first time, and revealed plans to launch a "second wave of legislative reform" following the upcoming legislative elections ${ }^{12}$ In May the following year, the Government Reform Commission also made a policy recommendation linking to two reform demands. ${ }^{13}$ During the legislative elections, the DPP organized the "Action Alliance for the Reform of the Legislature" advocating a "reduction in the number of seats in the legislature to under 150, a single-member dual-ballot system, and a legislative term of four years." These policies formed a major part of the party's policy platform for the upcoming elections. In August the same year, Chen Shui-bian in his capacity as party chairman issued instructions to the party's Central Standing Committee, requesting the DPP party caucus to complete work on constitutional and legal revisions within a year, producing a constitutional reform bill to introduce the single-member dual-ballot system and reduce the number of seats in the legislature to $150 .{ }^{14}$

\footnotetext{
${ }^{11}$ See China Times. December 7, 2000. 4th edition (in Chinese).

${ }^{12}$ See United Daily News. October 26, 2001 (in Chinese).

${ }^{13}$ The fifth committee meeting decided that the numbers for each category of legislator should be as follows:

1. The total number of legislators should be adjusted to 150 .

2. There should be 90 district legislators, with 84 districts for special municipalities and cities/counties, allocated according to population, with each city/county receiving at least one member. Each district shall elect one member by plurality voting. Aboriginals should elect six members by plurality voting.

3. 60 at-large members shall be elected, including four members representing overseas compatriots, according each party's vote share.

4. There should be at least one woman for every four candidates in party lists. It was also recommended that in elections for district members, each party should ensure that at least $25 \%$ of the candidates nominated were female.

${ }^{14}$ Chen Shui-bian concurrently served as president and party chairman between July 2002 and December 2004, and between
} 
Subsequently, in August 2003, Chen began a referendum signature campaign to halve the legislative seats, combining the referendum topic with the issue of legislative reform. Using this approach, Chen legitimized the referendum and helped shape the DPP's reform image(Yang,2003:65). Subsequently, in September of the same year at the seventeenth anniversary of the founding of the DPP, Chen put forward the issue of "establishing a new constitution," and in November proposed "formulating a constitution" together with halving of the legislative seats. From his manipulation of these issues, we find that Chen Shui-bian constantly tied the question of halving the legislative seats with other issues in order to obtain legitimacy and create an atmosphere of reform in which to make his electoral appeals.

Aside from DPP's continuing focus on electoral issues, after the KMT and PFP launched a joint ticket of Lien Chan and James Soong for the 2004 elections, they needed to regain the policy initiative and adopt a more active role. First, in November 2003, the KMT-PFP alliance co-sponsored a constitutional amendment, proposing a single-member dual-ballot system as well as the abolition of the National Assembly and the introduction of a presidential system. In addition, with regard to the referendum issue proposed by the DPP, the KMT-PFP alliance proposed the use of referenda for constitutional reform. Subsequently, they also criticized the DPP's proposal to reduce the number of legislative seats to 150 for not going as far as the original proposal to halve the number of seats. The proposal of the KMT-PFP alliance to halve the number of legislators to 113 won the public support of DPP grandee Lin Yi-hsiung in December 2003, who jointly launched a petition drive with Nobel Prize winner Yuan T. Lee to "halve the number of legislators to 113."In response, in December of the same year, the DPP Central Standing Committee revised its demands for constitutional reform to a single-member dual-ballot system and a halving of the seats in the Legislative Yuan to 113 seats. $^{15}$ Subsequently, the joint proposals for a single-member dual-ballot system and halving of the seats in the Legislative Yuan to 113 seats gained unstoppable momentum. In March 2004, the Legislative Yuan Constitutional Reform Committee passed amendments to Additional Article 4 of the Constitution to the main assembly for the second and third readings before the upcoming presidential election. However, on March 19, 2004, the Non-Partisan Solidarity Union made a proposal calling for negotiation between party caucuses, meaning the constitutional amendments failed to pass before the presidential election. In August the same year, both the KMT and DPP passed their own versions of the law for the extraordinary session of the Legislative Yuan. Both versions included a single-member dual-ballot system and a halving of the seats in the Legislative Yuan to 113 seats. Due to the upcoming sixth legislative elections in December of the same year, both parties faced strong pressure from public opinion and were anxious to avoid losing the public's trust. Therefore, in August during an extraordinary session of the Legislative Yuan, the third reading of the constitutional amendments reforming the legislature was passed as amendments to Additional Article 4 of the Constitution. The following year, the ad hoc National Assembly meeting passed the constitutional amendments by 249 votes to 48 . These changes to the electoral system for the Legislative Yuan, which would have profound effect on party development and electoral politics in Taiwan, were to be introduced from the Seventh Legislative Elections in 2007.

\section{(3) Path Dependence in Reform to the Electoral System for the Legislative Yuan}

Comparing the constitutional reform process for the single-member dual-ballot MMM system and the halving of the seats in the Legislative Yuan, we find that the two reform processes were characterized by different timings and a type of path-dependent relationship. The most important factor in the development of this path dependence was the widespread popular support for halving of the seats in the Legislative Yuan, which strengthened the legitimacy of legislative reform. For this reason, the halving of seats became a political demand that had to be constantly repeated during both parties' electoral mobilization efforts. In addition, the limitations created by other institutional factors including the formal resolution of the Government Reform Commission which strengthened reform demands and the dominance of the KMT and DPP in defining election issues, it became increasingly difficult to reverse the momentum of the legislative reform proposal for a single-member dual-ballot parallel system and halving of the seats in the Legislative Yuan. Therefore, the constitutional amendments were eventually passed by the Legislative Yuan and a subsequent ad-hoc meeting of the National Assembly.

The proposals for a single-member dual-ballot system and halving of the seats in the Legislative Yuan appeared both during the mid-1990s and following the first transition of power in 2000. Subsequently, in 2001, they were combined into the same proposal for legislative reform, and became an important part of the electoral platform for both ruling and opposition parties. In particular, after the when the DPP became the largest party in the Legislative Yuan, a consensus gradually Fifth Legislative Elections emerged between the two parties on legislative reform. Relatively speaking, due to the large decline in its seat share following the PFP split, the reform demands were even more critical for the KMT to generate a positive image for the party. Therefore, pushing forward with legislative reform became a common cause for both major parties. As a result, the proposals won increasing political support, even if some differences remained

October 2007 and January 2008.

${ }^{15}$ See United Daily News. December 31, 2003 (in Chinese). 
between the parties on the details of the proposals. However, in overall terms, the reform trend had become set. From the perspective of path dependence, the increasing political support for the reform program and benefits produced by pursuing reform reveal the self-reinforcing mechanisms of the original path, and the increasing costs of switching paths, "locking in" a particular development path. This issue was also further intensified by the presidential election, with the legislative reform proposal becoming a marker of a "pro-reform" or "anti-reform" position. Although the PFP and TSU switched their stance to opposition to the proposal at the last minute, they were unable to change to established direction of reform, and the KMT and DPP ultimately jointly ensured the passage of the constitutional amendment, which was formally incorporated into the Additional Articles of the Constitution by an ad-hoc meeting of the National Assembly. In short, initiatives for legislative reform that emerged in the 1990s developed into a political consensus within the National Development Conference. However, due to differences between the two parties on the use of the MMM or MMP system, these changes were not incorporated into the fourth revision to the Constitution. However, following the first transition of power, the government now had a minority of seats in the legislature. Conflict between emerged between the two branches of government as a result of the legislature's obstruction of the executive, producing new demands for legislative reform, meaning halving the seats in the Legislative Yuan. The legislative reform proposal put forward by the government of the time not only won the support of the majority of public opinion, due to party competition, it also became the main policy proposal for both parties. The halving of legislative seats therefore largely replaced the single-member dual-ballot system as the major reform proposal. To some extent, this can also be regarded as a change in political preferences following the transition of power in 2000 as a result of the division in the Pan-Blue camp and the emergence of the PFP and TSU, producing a multi-party system. Following the Fifth Legislative Election, the DPP emerged as the largest party, meaning that it had different calculations about the impact of electoral reform, and started to adjust its preferences. In addition, the high level of popular support and multiple instances of public declarations of support from the political parties smoothed the path toward reform. As a result, the major parties continued to engage in political consultations on electoral reform, generating a consensus on the political process of amending the constitution. The emergence and intervention of the many historical contingencies described above caused changes in the ideal innovation and preferences for legislative reform, gradually producing a process of institutional change. In the next section, we discuss the institutional legacy created by the application of the new system in the Seventh Legislative Elections.4. The Institutional Legacy of the New Electoral System

The previous section was focused on describing the process by which demands for legislative reform eventually became passed as constitutional amendments. This section tries to understand the formation of the new electoral system, as well as the reasons for the constitutional revisions and their subsequent impact, using the perspective provided by path dependence to understand the institutional legacies of the new electoral system. From the process described in the preceding session, we find that the DPP's institutional preferences changed due to the impact of contingent events. The change in objective conditions caused by contingent events influenced institutional choice. Following the Fifth Legislative Elections, the DPP's institutional choice for the electoral system changed from the MMP to MMM system, producing a new intra-party consensus. Furthermore, following the first transition of power, the halving of the seats in the Legislative Yuan largely replaced the single-member dual-ballot system as the major demand for reform(Lin,2006:30).

(1) The Reasons behind the Emergence of Demands for Legislative ReformYung-ming Hsu analyses party vote shares in the 1998 and 2001 legislative elections, when applied to constituencies for county and city councilor and National Assembly members. On this basis, he arranges the order of preference for SNTV, the MMP system, and the parallel system among each party. Using the simulation, Hsu explains why the DPP's institutional preferences for the new electoral system changed from the single-member dual-ballot MMP system that it had supported for many years to the single-member dual-ballot MMM system. In particular, the simulation of voting in the 2001 legislative election found that the DPP and KMT shared the same institutional preference for the MMM. This is because the MMM system would squeeze the share of seats won by smaller parties to the benefit of the major parties. In particular, with the split in the Pan-Blue vote, the DPP's share of seats using single member constituencies increased significantly. Combined with the decline of the KMT in both seat share and party vote share, the MMM system became the DPP's preferred choice over SNTV. Finally, Hsu concludes that the DPP's preferred electoral system changed from the MMP system in 1998 to the MMM system in 2001, and predicts that unless there is a new round of party splits and mergers, the MMM system will continue to receive more political support than the MMP system. The likely effect of this is a shrinking of the space for small parties, pushing Taiwan from a multi-party system to a two party system(Hsu,2002:6-16).

This study uses interviews to further validate Hsu's conclusions and predictions. Liang Wen-chieh ${ }^{16}$ believes that, aside

\footnotetext{
${ }^{16}$ Liang Wen-chieh was employed at the DPP Policy Research and Coordinating Committee for a long period, and was executive vice president of the Policy Research and Coordinating Committee during the constitutional reform process.
} 
from the confidence generated by becoming the largest party in the Legislative Yuan after 2001, the DPP switched their support to a parallel system because it believed that faced with the existing multi-party system, the MMP system would benefit smaller parties. Instead, the DPP chose the MMM because they wanted to move Taiwan toward a two-party system, and that parallel voting was beneficial to the DPP under the current multi-party system. However, Liang Wen-chieh also stated that viewed from the results of the Seventh Legislative Election, the DPP's choice was overly optimistic. In fact, the reorganization of the party system predicted by Hsu did not take place before the constitutional amendment bill was produced, but rather as a result of the "KMT-PFP merger" prior to the Seventh Legislative Elections of 2008. If this reorganization of the party system had taken place before the constitutional reform had been passed, it may have produced changes in the DPP's institutional preferences. However, after the constitutional amendment had passed, the DPP's institutional choices made under the existing multi-party system produced a very outcome under a two-way cleavage between the Pan-Blue and Pan-Green sides, meaning that in the gap between the KMT and DPP in seat share for constituency legislators in the Seventh Legislative Election was as a high as $60.27 \%$, while even the gap for legislators-at-large reached $17.64 \%$ (see Table 1).

Table 1. Comparison of Performance of Two Major Parties in Seventh Legislative Election, 2008 (\%)

\begin{tabular}{|c|c|c|c|c|c|c|}
\hline Party & $\begin{array}{l}\text { Share of Vote } \\
\text { for } \\
\text { Constituency } \\
\text { Election (1) }\end{array}$ & $\begin{array}{l}\text { Share of Seats } \\
\text { for } \\
\text { Constituency } \\
\text { Election (2) }\end{array}$ & $\begin{array}{l}\text { Difference } \\
(2-1)\end{array}$ & $\begin{array}{l}\text { Share of Vote } \\
\text { for At-Large } \\
\text { Election (3) }\end{array}$ & $\begin{array}{l}\text { Share of Seats } \\
\text { for At-Large } \\
\text { Election (4) }\end{array}$ & $\begin{array}{l}\text { Difference } \\
(4-3)\end{array}$ \\
\hline KMT & $53.48 \%$ & $\begin{array}{l}78.08 \% \\
(57 \text { seats) }\end{array}$ & $24.6 \%$ & $51.23 \%$ & $\begin{array}{l}58.82 \% \\
(20 \text { seats) }\end{array}$ & $7.59 \%$ \\
\hline DPP & $38.65 \%$ & $\begin{array}{l}17.81 \% \\
(13 \text { seats) }\end{array}$ & $-20.84 \%$ & $36.91 \%$ & $\begin{array}{l}41.18 \% \\
\text { (14 seats) }\end{array}$ & $4.27 \%$ \\
\hline $\begin{array}{l}\text { Difference } \\
\text { between parties }\end{array}$ & $14.83 \%$ & $\begin{array}{l}60.27 \% \\
(44 \text { seats })\end{array}$ & $45.43 \%$ & $14.32 \%$ & $\begin{array}{l}17.64 \% \\
(6 \text { seats })\end{array}$ & $3.32 \%$ \\
\hline $\begin{array}{l}\text { Source: } \\
\text { http://db.cec.gov.t }\end{array}$ & $\begin{array}{l}\text { Central } \\
\text { w/histMain.jsp? }\end{array}$ & $\begin{array}{l}\text { Election } \\
\text { yoteSel=2012010 }\end{array}$ & $\begin{array}{l}\text { Commission } \\
\text { A2, refer to }\end{array}$ & $\begin{array}{l}\text { election } \\
2008: 64 \text {. }\end{array}$ & database & website: \\
\hline \multicolumn{7}{|c|}{$\begin{array}{l}\text { In addition, during the Eighth Legislative Elections in 2012, even though Ma Ying-jeou was in office, and negative } \\
\text { feelings toward the DPP as a result of the corruption and governance failures of the Chen Shui-bian regime had already } \\
\text { decline significantly, the gap between the KMT and DPP in seat share for constituency legislators in the Eighth } \\
\text { Legislative Election was still as a high as } 28.76 \% \text {, while the gap for legislators-at-large was } 8.82 \% \text { (see Table 2). This } \\
\text { shows that even as negative political factors declined, and the gap for at-large legislators had narrowed to within an } \\
\text { acceptable range, there was still a considerable gap for constituency legislators, posing serious questions for } \\
\text { representatives of the legislature. Although the current election system is beneficial to the largest party in the legislature, } \\
\text { it does not meet the democratic requirements of reflect public opinion or the representatives of elected members. As a } \\
\text { result, the Legislative Yuan does not represent the real spectrum of public opinion in Taiwan. } \\
\text { Table 2. Comparison of Performance of Two Major Parties in Eighth Legislative Election, } 2012 \text { (\%) }\end{array}$} \\
\hline Party & $\begin{array}{l}\text { Share of Vote } \\
\text { for } \\
\text { Constituency } \\
\text { Election (1) }\end{array}$ & $\begin{array}{l}\text { Share of Seats } \\
\text { for } \\
\text { Constituency } \\
\text { Election (2) }\end{array}$ & $\begin{array}{l}\text { Difference } \\
(2-1)\end{array}$ & $\begin{array}{l}\text { Share of Vote } \\
\text { for At-Large } \\
\text { Election (3) }\end{array}$ & $\begin{array}{l}\text { Share of Seats } \\
\text { for At-Large } \\
\text { Election }(4)\end{array}$ & $\begin{array}{l}\text { Difference } \\
(4-3)\end{array}$ \\
\hline KMT & $48.18 \%$ & 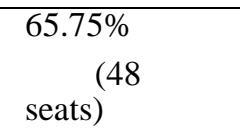 & $17.57 \%$ & $44.55 \%$ & $\begin{array}{l}\begin{array}{l}47.06 \% \\
(16\end{array} \\
\text { seats) }\end{array}$ & $2.51 \%$ \\
\hline DPP & $43.80 \%$ & $\begin{array}{l}36.99 \% \\
(27 \\
\text { seats })\end{array}$ & $-6.81 \%$ & $34.62 \%$ & $\begin{array}{l}38.24 \% \\
\quad(13 \\
\text { seats })\end{array}$ & $3.63 \%$ \\
\hline $\begin{array}{l}\text { Difference } \\
\text { between } \\
\text { parties }\end{array}$ & $4.38 \%$ & $\begin{array}{l}28.76 \% \\
(21 \\
\text { seats })\end{array}$ & $24.38 \%$ & $9.93 \%$ & $\begin{array}{l}8.82 \% \\
\text { seats })\end{array}$ & $1.12 \%$ \\
\hline
\end{tabular}

Source: Central Election Commission election database, website:

http://db.cec.gov.tw/histMain.jsp?voteSel=20120101A2, compiled by author.

Interviewed on December 9, 2008. 
A second interviewee Hsu Chih-hsiung ${ }^{17}$ emphasized that the constitutional reform to halve the legislative seats set the number of seats at 113. However, since the total number of seats under the MMP system is not stable, the MMM was chosen instead. In addition, given that the old SNTV system was also a type of MMM system, the new MMM system was a continuation of the old system in this respect. The version proposed at the time by the Government Reform Commission would have reduced the number of seats to 150 , with the ratio between district and at large legislators set to 6:4. This was discussed four times by working group meetings, and was calculated by scholars as being most favorable to the DPP. However, unfortunately there was a significant difference between the outcome of the reform drive and negotiations carried out by the DPP party caucus and the original version. Before the Government Reform Commission had reached a decision, the DPP party caucus in the legislature held a public hearing at the Legislative Yuan on constitutional reform to the legislature. ${ }^{18}$ Aside from twenty-three members of the party caucus, many scholars working on election studies also attended the public hearing. ${ }^{19}$ In response to the two major political demands for reform of the legislature, aside from Tzong-li system, other scholars were noncommittal. However, there was a clear consensus on the number of seats in the legislature. While scholars accepted a reduction in the number of seats, they were opposed to cutting the number of seats in half. Coincidentally, Tzong-li MMM system with a ratio of 6:4 between district and at-large members, and a total of 160 seats, was very close to the version produced by the Government Reform Commission working group which Hsu chaired. Hsu argued that the German MMP system should not be adopted since it allocates seats entirely on the basis of proportional representation, unlike Taiwan's existing system of parallel voting. In addition, the MMP system produces many small parties. Even though Germany set a five percent threshold for representation, the system has still produced many small parties. So if a MMM were adopted with district members making up sixty percent and at-large members making up forty percent, it was believed that the larger number of district members should reduce the number of parties, promoting political stability. Of the party caucus members, a majority advocated the MMM system However, they were not agreed on the reduction in the number of seats. At the same time, the party's Policy Research and Coordinating Committee advocated MMM, a reduction in the number of seats to 120, and a fifty-fifty division in the number of district and at-large members. From the views expressed at the public hearing, it is clear that while a consensus to support the MMM had emerged within the party, only a minority supported halving the number of legislative seats. However, ultimately, the revisions to the constitution reduced the number of seats by half to 113 , with $73(65 \%)$ seats allocated to district members, 34 seats (30\%) allocated to at-large members, and 6 seats reserved for aboriginal legislators $(5 \%)$.How was this version passed despite the fact that no consensus had emerged within the DPP on the reduction in the number of seats? Looking at internal party factors, Liang Wen-chieh believes that this was related to the current party chairman Chen Shui-bian's active support for Lin Yi-hsiung's proposal to halve the number of seats in the Legislative Yuan. Hsu Chih-hsiung believes the answer lies in the confidence that Chen Shui-bian had from his two consecutive election victories. In the same year, Lin Yi-hsiung continued to exert pressure on Chen Shui-bian through his campaign for "honesty and credibility as the foundation of the country." This was clear demand to fulfill the promise made in the campaign for the Fifth Legislative Elections in 2001. However, the halving the seats became a part of the demands for legislative reform as a result of the political chaos produced by the government having a legislative minority following the first transition of power. Emerging from the ideas of "reducing quantity to control quantity" and opposition to the constraints placed on the executive by the legislature, the formation and promotion of this political preference with regard to legislative reform had a crucial influence on the subsequent implementation of the new electoral system. In the next session, we discuss the impact of the new electoral system on the political map in the legislature.

\section{(2) The Impact of the New Electoral System}

Yu \& Chang(2008) use Loosemore-Hanby D (deviation) to measure the disproportionality in legislative election under the old and new electoral system (see Figure 1). They argue that during the process of institutional choice, the blind pursuit of political stability meant that the semi-proportional features of the existing SNTV were overlooked, meaning that the mixed system that emerged as a compromise outcome failed to balance governability and proportionality. One of the reasons for this imbalance was the distribution of seats. When deciding how to distribute seats, the principle of

\footnotetext{
17 Hsu Chih-hsiung was the representative of the Executive Yuan in the Legislative Reform Working Group of the Government Reform Commission established by the Presidential Office, and was also the chairman of the Mongolian and Tibetan Affairs Commission at the time. Interviewed on December 27, 2008.

${ }^{18}$ Information is from the DPP party caucus in the Legislative Yuan, the meeting was held on April 12 in the $12^{\text {th }}$ Meeting Room of the Legislative Yuan and chaired by Luo Wen-jia.

19 Attended by scholars, including Wang Yeh-lih Wang, Hsu Tzong-li, Hawang Shiow-Duan, Liu I-chou, and Tsai Tzung-Jen. Of these, Hsu Tzong-li and Tsai Tzung-Jen were members of the legislative reform working group in the Government Reform Commission, while according to the interview with Hsu Chih-hsiung, Wang Yeh-lih and Hawang Shiow-Duan were invited to the meeting by the working group.
} 
fair representation must be followed, meaning that the population in each electoral district must be roughly equal. However, under the new electoral system, constituency boundaries were drawn according to existing local government boundaries. The rule that each county must have at least one representative resulted in malapportionment of seats. For instance, Hsinchu County with a population of 475,928 and Lienchiang County with a population of just 9,786 were both allocated one seat, producing a serious gap in the value of each vote. Another factor was the new electoral system. $\mathrm{Yu}$ and Chang analyze the disproportionality in the new electoral system for district members, at-large members, and aboriginal members. Their results show that the overall D value for the Seventh Legislative Elections was $24.62 * 0.65$ $+11.86 * 0.3+11.78 * 0.05=20.15^{20}$ (see Table 3 ).

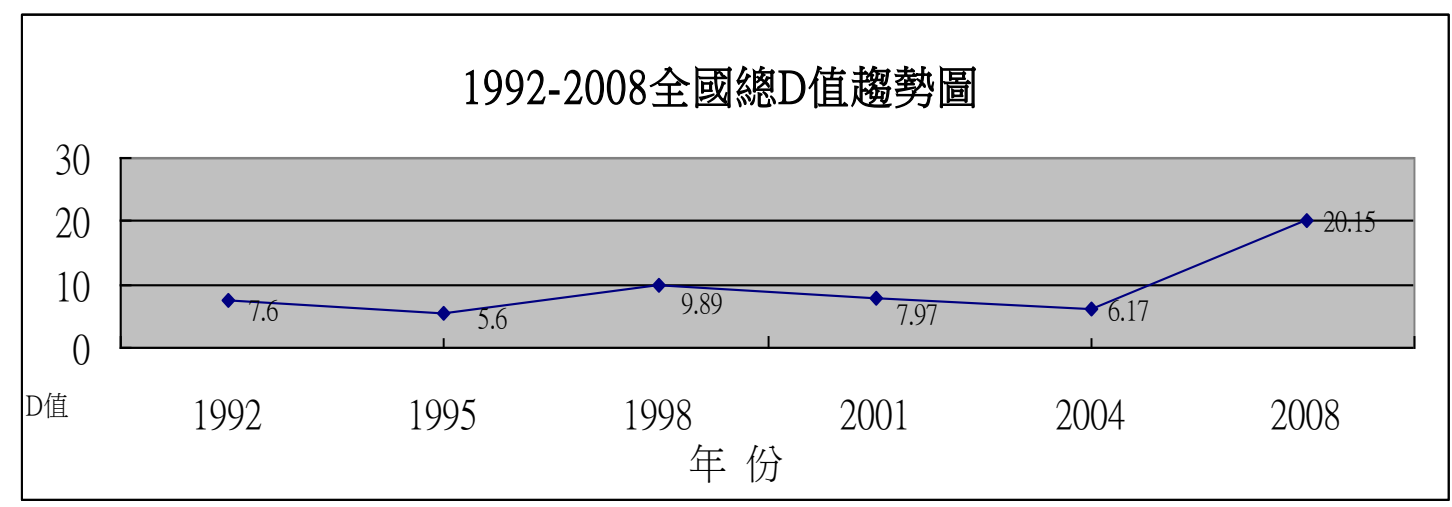

Figure 1. Historical D-Value for Legislative Elections, 1992-2008

Source: Yu, Ching-Hsin \& Yu-Cheng Chang. 2008. "Election Systems and Disproportional Outcomes: The Case of the Mixed System in Taiwan's 2008 Legislative Elections", Figure 3

Table 3. D-values for District Members, At-Large Members, and Aboriginal Members in 2008 Legislative Elections

\begin{tabular}{|c|c|c|c|c|c|c|c|c|c|c|}
\hline 2008 & KMT & & & DPP & & & Others & & & \\
\hline \multirow[t]{2}{*}{ District } & Seat share & Vote share & S-V & Seat share & Vote share & S-V & Seat share & $\begin{array}{l}\text { Vote } \\
\text { share }\end{array}$ & $\mathrm{S}-\mathrm{V}$ & \\
\hline & $78.08 \%$ & $53.48 \%$ & 24.60 & $17.81 \%$ & $38.65 \%$ & -20.84 & $4.11 \%$ & $7.87 \%$ & -3.76 & 24.60 \\
\hline \multirow[t]{2}{*}{ At-Large } & Seat share & Vote share & S-V & Seat share & Vote share & S-V & Seat share & $\begin{array}{l}\text { Vote } \\
\text { share }\end{array}$ & $\mathrm{S}-\mathrm{V}$ & $\begin{array}{l}\mathrm{D}- \\
\text { value }\end{array}$ \\
\hline & $58.82 \%$ & $51.23 \%$ & 7.59 & $41.18 \%$ & $36.91 \%$ & 4.27 & 0 & $11.86 \%$ & -11.86 & 11.86 \\
\hline \multirow[t]{2}{*}{ Aboriginal } & Seat share & Vote share & S-V & Seat share & Vote share & S-V & Seat share & $\begin{array}{l}\text { Vote } \\
\text { share }\end{array}$ & $\mathrm{S}-\mathrm{V}$ & $\begin{array}{l}\mathrm{D}- \\
\text { value }\end{array}$ \\
\hline & $66.67 \%$ & $54.89 \%$ & 11.78 & 0 & $-6.76 \%$ & -6.76 & $33.35 \%$ & $38.35 \%$ & -5.02 & 11.78 \\
\hline
\end{tabular}

Source: Yu, Ching-Hsin \& Yu-Cheng Chang. 2008. "Election Systems and Disproportional Outcomes: The Case of the Mixed System in Taiwan's 2008 Legislative Elections", revised by author.

Figure 1 and Table 3 show the level and deviation of disproportionality under the new electoral system. We find that the gap between vote share and seat share for the DPP was larger than the total for other small parties. Therefore, the implementation of MMM system not only reduced the political space for small parties, it had an even more adverse effect on the second largest party in the legislature. If the DPP's institutional preference had not switched from a MMP system to a MMM system, assuming a halving of the number of seats, what would have been the outcome in terms of seat share given the vote shares in the Seventh Legislative Elections? What is the difference in disproportionality between the two systems?

In addition, the halving of the seats in the Legislative Yuan produced another form of disproportionality, leading to the phenomenon of "double disproportionality." This "double disproportionality" did not just make small parties unviable, it even pushed Taiwan towards a dominant party system.

Table 4 shows vote shares and seat shares for the legislative elections in 2012. These elections took place under the

${ }^{20}$ According to the authors' calculations, the national D-value should be $24.60 * 0.65+11.86 * 0.3+11.78 * 0.05=20.137$. 
presidency of Ma Ying-jeou and a decline in the negative political impact on the DPP of the Chen Shui-bian regime. Furthermore, the performance of Ma's regime had not met expectations, meaning that the DPP had returned to its traditional support levels. However, even in this case, the framework of the electoral system continued to produce disproportionality. While the DPP achieved a less disproportional outcome than the KMT in the at-large elections, it still suffered from significant disproportionality in both the district and aboriginal elections.

Table 4. D-values for District Members, At-Large Members, and Aboriginal Members in 2012 Legislative Elections

\begin{tabular}{|c|c|c|c|c|c|c|c|c|c|c|}
\hline 2012 & KMT & & & DPP & & & Others & & & $\begin{array}{l}\text { D- } \\
\text { value }\end{array}$ \\
\hline \multirow[t]{2}{*}{ District } & $\begin{array}{l}\text { Seat } \\
\text { share }\end{array}$ & $\begin{array}{l}\text { Vote } \\
\text { share }\end{array}$ & S-V & $\begin{array}{l}\text { Seat } \\
\text { share }\end{array}$ & $\begin{array}{l}\text { Vote } \\
\text { share }\end{array}$ & $S-V$ & $\begin{array}{l}\text { Seat } \\
\text { share }\end{array}$ & $\begin{array}{l}\text { Vote } \\
\text { share }\end{array}$ & $S-V$ & \\
\hline & $65.75 \%$ & $48.18 \%$ & 17.57 & $36.99 \%$ & $43.80 \%$ & -6.81 & $4.11 \%$ & $8.02 \%$ & -3.76 & 17.57 \\
\hline \multirow[t]{2}{*}{ At-Large } & $\begin{array}{l}\text { Seat } \\
\text { share }\end{array}$ & $\begin{array}{l}\text { Vote } \\
\text { share }\end{array}$ & S-V & $\begin{array}{l}\text { Seat } \\
\text { share }\end{array}$ & $\begin{array}{l}\text { Vote } \\
\text { share }\end{array}$ & $S-V$ & $\begin{array}{l}\text { Seat } \\
\text { share }\end{array}$ & $\begin{array}{l}\text { Vote } \\
\text { share }\end{array}$ & $S-V$ & $\begin{array}{l}\text { D- } \\
\text { value }\end{array}$ \\
\hline & $47.06 \%$ & $44.55 \%$ & 2.51 & $38.24 \%$ & $34.62 \%$ & 3.62 & $14.70 \%$ & $20.83 \%$ & -6.13 & 6.13 \\
\hline \multirow[t]{2}{*}{ Aboriginal } & $\begin{array}{l}\text { Seat } \\
\text { share }\end{array}$ & $\begin{array}{l}\text { Vote } \\
\text { share }\end{array}$ & $S-V$ & $\begin{array}{l}\text { Seat } \\
\text { share }\end{array}$ & $\begin{array}{l}\text { Vote } \\
\text { share }\end{array}$ & $S-V$ & $\begin{array}{l}\text { Seat } \\
\text { share }\end{array}$ & $\begin{array}{l}\text { Vote } \\
\text { share }\end{array}$ & $S-V$ & $\begin{array}{l}\mathrm{D}- \\
\text { value }\end{array}$ \\
\hline & $66.67 \%$ & $51.51 \%$ & 15.16 & 0 & $4.27 \%$ & -4.27 & $33.33 \%$ & $44.22 \%$ & -5.02 & 15.16 \\
\hline
\end{tabular}

Source: Central Election Commission election database, website:

http://db.cec.gov.tw/histMain.jsp?voteSel=20120101A2, compiled by author.

From Table 4, we calculate the overall D-value as follows: $17.57 * 0.65+6.13 * 0.3+15.16 * 0.05=14.01$. Based on Yu and Chang's research (Figure 1), we simulate the trend in the overall D-value for elections between 1992 and 2012.

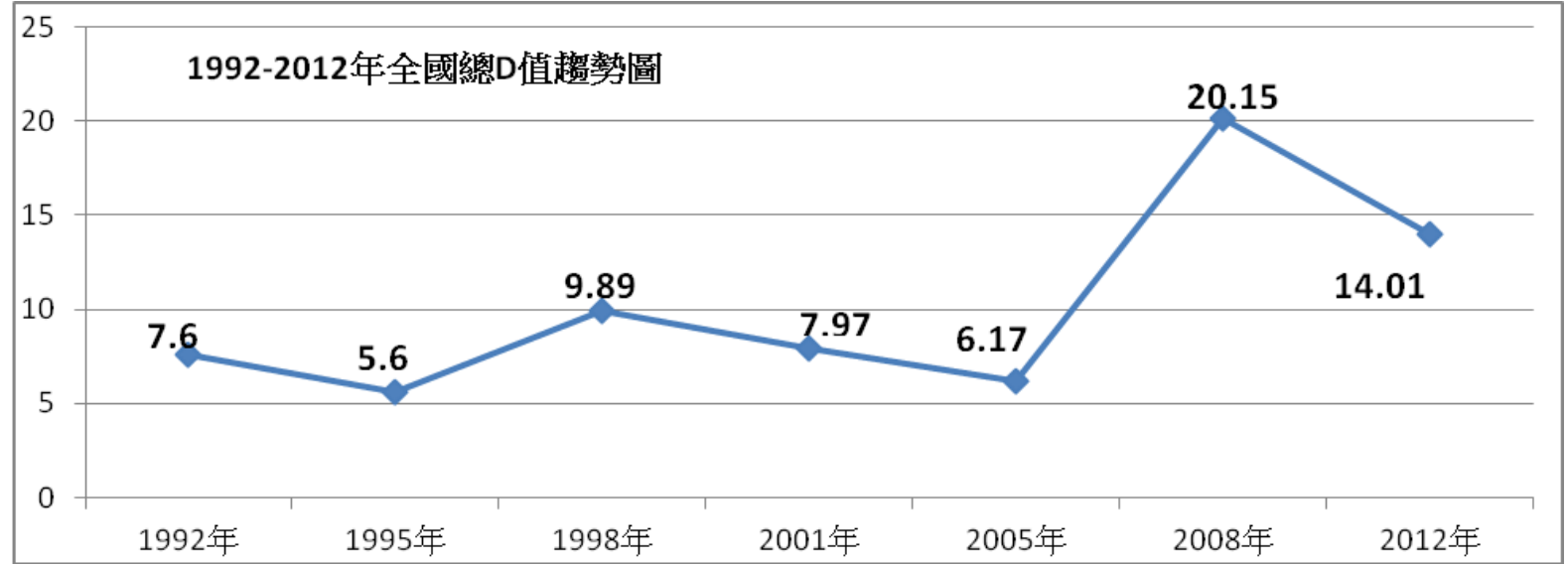

Figure 2: Historical D-Value for Legislative Elections, 1992-2012

Source: Central Election Commission election database, website: http://db.cec.gov.tw/histMain.jsp?voteSel=20120101A2, compiled by author.

Comparing the figures in Table 4 and Figure 2 with Table 3 and Figure 1, we can understand the different in disproportionality between the MMM system and MMP system. We can also see that if a MMP system was used, the difference in disproportionality with the previous SNTV system would not be large. However, the effect of the disproportionality in the new MMM system can be seen from a comparison of the above figures. As a result, the disproportionality in the results for the Seventh Legislative Election caused interest and surprise, as well as calls for a new round of reforms. However, aside from the two major legislative reforms, the constitutional amendment passed by an ad-hoc National Assembly meeting in 2005 incorporated the requirement for a referendum to pass amendments to the constitution as Additional Article 12. ${ }^{21}$ From a path dependent perspective, this makes it very hard to reverse the constitutional reforms to the legislature.

\footnotetext{
${ }^{21}$ Additional Article 12 of the Constitution: Amendment of the Constitution shall be initiated upon the proposal of one-fourth of the total members of the Legislative Yuan, passed by at least three-fourths of the members present at a meeting attended by at least
} 


\section{Conclusion}

Lin(1997) has argued that electoral systems are maintained because political elites elected by a particular system have a tendency to want to maintain that same system. Furthermore, elites are more likely than non-elites to make institutional choices. Therefore, it is very easy to see that institutional choices are derived from changes in elites' preference structure. However, changes in preferences are produced by contingent events. These contingent events change the objective situation, meaning that the preferences of elites also changes. In the process from the formation of the constitutional amendment bill to the final passage of the Seventh Constitutional Amendment, the new electoral system was proposed in the mid-1990s, but no agreement was reached by the end of the 1990s. However, following the historical contingency of the first transition of power, the government now only had a minority in the legislature, which was now characterized by a multi-party system. Constrained by the political situation, DPP launched a new proposal for legislative reform - halving the seats in the Legislative Yuan. This political demand received a high level of popular support, providing a new impetus for legislative reform. Furthermore, this political demand was linked with the single-member dual-ballot system in the election campaign. However, after the election platform delivered more votes and seats, there was an increased chance that the new system would be implemented. With the DPP becoming the largest party in the legislature, its institutional preference gradually shifted from the MMP system to the MMM system. In addition, as the KMT were gradually more willing to accept the halving of the seats in the Legislative Yuan, a consensus on the new electoral system began to emerge. After this political consensus had developed into a constitutional amendment bill and finally a revision to the Additional Articles of the Constitution, the party system was reoriented, with competition shifting to the cleavage between Pan-Blue and Pan-Green camps. The double disproportionality caused by the single-member dual-ballot MMM system and the halving of the seats in the Legislative Yuan meant that the institutional choice it made based on its interests under a multiparty system eventually proved to be very damaging for the party. As a result, following the election, new voices for reform began to emerge. However, the incorporation of referenda into the constitution locked in this institutional choice, producing a new institutional legacy. Following the perspective of path dependence, the increasing support for the reform program and benefits produced by pursuing reform reveals the self-reinforcing mechanisms of the original path, and the increasing costs of switching paths, "locking in" a particular development path. The mechanisms may even mean that institutions become locked-in in an inefficient state. Once institutions are "locked in," it becomes very difficult for them to change. Often change is only possible through the intervention of external forces or exogenous variables. It has possible that the demands for constitutional reform that emerged with the Sunflower Movement of early 2014, the defeat for the KMT in the 2014 local elections, and as the governance failures of the central government, as well as the new KMT chairman Eric Chu's public support for a parliamentary system, have created new opportunities for possible constitutional reforms in the future. This may mean present an opportunity to remove the lock of the original path dependence in the electoral system. Future research on the electoral system for the legislature can continue to observe and investigate this issue.

\section{Reference}

Central Daily News. December 31, (2003). (in Chinese).

Central Daily News. December 7, (1995). $4^{\text {th }}$ edition (in Chinese).

Chiang, T. (2001). Evaluation on Halving of the Seats in the Legislative Yuan. Taipei: DPP Policy Research and Coordinating Committee (in Chinese)

China Times. December 25, (1996). $2^{\text {nd }}$ edition (in Chinese).

China Times. December 7, (2000). $4^{\text {th }}$ edition (in Chinese).

China Times. June 6, (1997). $2^{\text {nd }}$ edition (in Chinese).

China Times. March 25, (1997). $3^{\text {rd }}$ edition (in Chinese).

Chou, Y. J., \& Chun-chi, Y. (2001). The Possibility and Suitability of Multi-Member Districts, in Yeong-chin Su ed. Legislative Reform: Taiwan's New Constitutional Arrangements. Taipei: New Taiwanese Cultural Foundation.

Commons Daily. March 15, (1997). 12 $2^{\text {th }}$ edition (in Chinese).

DPP Policy Research and Coordinating Committee. (2005). Local Discussion Forum for the Second Stage Constitutional Reform: Handbook. Taipei: DPP Policy Research and Coordinating Committee (in Chinese)

Duverger, M. (1986). Duverger's Law: Forty Years Later, in Bernard Grofman, and Arend Lijphart, eds., Electoral Law

three-fourths of the total members of the Legislative Yuan, and sanctioned by electors in the free area of the Republic of China at a referendum held upon expiration of a six-month period of public announcement of the proposal, wherein the number of valid votes in favor exceeds one-half of the total number of electors. The provisions of Article 174 of the Constitution shall not apply. 
and Their Political Consequences, New York: Agathon Press, 69-84.

Government Reform Commission. (2002) Resolutions from Fifth Committee Meeting, http://www.president.gov.tw/2_special/innovation/t6.html accessed December 13, 2008 (in Chinese). Hall, P., \& Taylor, R. (1996). Political Science and the Three New Institutionalisms, Political Studies, XLIV, 936-57.

Hsieh, J. F. (2001). Some Recommendations on Legislative Reform, in Yeong-chin Su ed. Legislative Reform: Taiwan's New Constitutional Arrangements. Taipei: New Taiwanese Cultural Foundation.

Hsu, Y. M. (2002). Simulating the Political Impact of the Single-Member Dual-Ballot System. New Century Thinktank Forum, 17, 6-16 (in Chinese).

Hall, P., \& Rosemary, T. (1996). Political Science and the Three New Institutionalism, Political Study, 44(4), 936-957.

Immergut, E. M. (1998). The Theoretical Core of the New Institutionalism, Politics \& Society, 26(1), 5-34. http://dx.doi.org/10.1177/0032329298026001002

Legislative Yuan Monthly editorial team. (2005). Legislative Yuan Monthly. Taipei: Legislative Yuan Monthly (in Chinese)

Liberty Times. (2002).

Lien, C. (2001). New Blueprint, New Impetus. Taipei: Commonwealth Publishing Co., Ltd (in Chinese).

Lin, C. S. (2006). Constitutional Anger and Rationality. China Times, May 8 (in Chinese).

Lin, K. M. (2000). History, Institutions, and Politics: Policy Analysis of Partial Liability and Referral Programs in Taiwan's National Health Insurance, presented at conference on Sociological Imagination under Globalization: State, Economy and Society. Taipei: National Taiwan University Department of Sociology and Taiwan Sociological Association (in Chinese).

Lin, J. W. (1997). Assessing the Forty-first House of Representatives Election in Japan. National Policy Dynamic Analysis, 155, 14-15 (in Chinese).

Lin, J. W. (1997). How is Electoral Reform Possible: On Japan's Electoral Reform. Taiwanese Political Science Review, 2, 62-101 (in Chinese).

Lin, S. P. ( 2002). Constitutional Politics. Taipei: Yuanzhao Press

Lin, S. P. (2005). Anomaly Arising and Paradigm Shift: Analyzing the Change of the Legislative Electoral System, National Policy Quarterly, 4(2), 29-56 (in Chinese).

North, D. (1990). Institutions, Institutional Change and Economic Performance. New York: Cambridge University Press.

Pierson, P., \& Theda, S. (2002). Historical Institutionalism and Contemporary Political Science. In Helen Milner \& Ira Katznelson. Eds., The State of the Discipline. New York: W. W. Norton.

Pierson, P. (2004). Politics in Time: History, Institutions, and Social Analysis. Princeton, NJ: Princeton University Press.

Rein, T., \& Matthew, S. S. (1989). Seats and Votes: The Effects and Determinants of Electoral Systems. New Haven: Yale University Press.

Sartori, G. (1976). Parties and Party Systems. Cambridge, Cambridge University Press.

Sartori, G. (1994). Comparative Constitutional Engineering: An Inquiry into Structure, Incentives, and Outcomes. New York: New York University Press.

Sheng, Shing-Y., \& Yih-yan, C. (2003). Political Cleavage and Party Competition: An Analysis of the 2001 Legislative Yuan Election. Journal of Electoral Studies, 10(1), 7-40 (in Chinese).

Shih-Ying, C. (2002). Reform of the Electoral System for the Legislative Yuan and the Transition Period: Reflection on the 2001 Legislative Election. Chinese Public Administration Review, 11(4), 1-24 (in Chinese).

Taiwan Daily. January 6, (1999). $4^{\text {th }}$ edition (in Chinese).

Taiwan Daily. May 24, (1997). $7^{\text {th }}$ edition (in Chinese).

Tsai, W. (2002). Comparison of Electoral Systems for Legislative Reform. Journal of Electoral Studies, 9(2), 117-150 (in Chinese).

United Daily News. (2001).

Wang, Y. L. (2008). Comparing Electoral Systems $5^{\text {th }}$ ed. Taipei: Wunan Press (in Chinese) 
Wang, Y. S. (1997). New Institutionalism. Taipei: Yangzhi Press (in Chinese)

Wu, H. J., \& Chuang, S. J. (2000). Assessment of Halving of the Seats in the Legislative Yuan, presented at seminar on Halving of the Seats in the Legislative Yuan. Taipei: Taiwan Association of University Professors (February 17) (in Chinese).

Wu, W. C. (1996). Introduction to Political Parties and Elections. Taipei: Wunan Press (in Chinese).

Yang, T. S. (2003). Looking at Taiwan's Constitutional Crisis from the Halving of Legislative Seats, in Yu-jen Chou (ed.). Constitutional Crisis and Opportunity. Taipei: National Policy Foundation (in Chinese).

Yu, C. H., \& Chang, Y. C. (2008). Election Systems and Disproportional Outcomes: The Case of the Mixed System in Taiwan's 2008 Legislative Elections presented at Annual Conference of the Taiwanese Political Science Association. Nantou: National Chi Nan University (in Chinese).

\section{(c) $\mathrm{EY}$}

This work is licensed under a Creative Commons Attribution 3.0 License. 